\title{
KAJIAN LITERASI KONSEP PROFESIONALISME MENGAJAR GURU
}

\author{
Rifqi Maulana ${ }^{1}$ \\ ${ }^{1}$ Mahasiswa Program Studi Teknologi Pendidikan Universitas Pendidikan Mandalika Mataram \\ E-mail: qiyowo18@gmail.com
}

\begin{abstract}
Abstrak: Penelitian ini bertujuan untuk mengetahui gambaran mengenai pengembangan profesi guru, untuk mengetahui gambaran tingkat kinerja guru, dan untuk mengetahui pengaruh pengembangan profesi guru terhadap kinerja guru. Inti kajiannya difokuskan pada faktor-faktor yang mempengaruhi kinerja guru, adapun faktor yang diteliti dalam penelitian ini adalah pengembangan profaesi guru. Metode penelitian yang digunakan adalah metode survey. Teknik pengumpulan data yang dilakukan dalam penelitian ini menggunakan angket.Teknik analisis data menggunakan regresi sederhana. Hasil penelitian ini menunjukkan: pengembangan profesi guru berada dalam kategori cukup efektif,dan kinerja guru berada pada kategori cukup tinggi; pengembangan profesi guru berpengaruh positif terhadap kinerja.
\end{abstract}

Kata Kunci: pengembangan profesi kinerja Guru.

\section{PENDAHULUN}

Istilah profesi tentunya sudah tidak asing lagi bagi kita. Guru, dokter, polisi, tentara merupakan beberapa contoh sebutan untuk sebuah profesi. Guru harus menjalani proses pendidikan lebih lanjut untuk meningkatkan kualitas profesionalannya. Antara profesi, profesional, proesionalisme, profesionalitas dan profesionalisme mempunyai pengertian yang saling berkaitan satu sama lain. Profesional menunjuk pada dua hal. Pertama, orang yang menyandang suatu profesi, misalnya "Dia seorang profesional". Kedua, penampilan seseorang dalam melakukan pekerjaannya yang sesuai dengan profesinya. Pengertian kedua ini profesional dikontraskan dengan "non-profesional" atau "amatir". Profesionalisme menunjuk pada komitmen para anggota suatu profesi untuk meningkatkan kemampuan profesionalnya dan terus-menerus mengembangkan strategi- strategi yang digunakannya dalam melakukan pekerjaan yang sesuai dengan profesinya. Sedangkan Profesionalisasi menunjuk pada proses peningkatan kualifikasi maupun kemampuan para anggota profesi dalam mencapai kriteria yang standar dalam penampilannya sebagai anggota suatu profesi.

Guru adalah sosok pendidik yang sebenarnya. Dalam UU RI Nomor 14 Tahun 2005 Tentang Guru dan Dosen Pasal 1 disebutkan bahwa guru adalah pendidik profesional dengan tugas utama mendidik, mengajar, membimbing, mengarahkan, melatih, menilai dan mengevaluasi peserta didik pada pendidikan anak usia dini jalur pendidikan formal, pendidikan dasar dan pendidikan menengah.Profesi sebagai seorang guru harus dipandang dari beberapa sisi kehidupan secara luas. Sejumlah rekomendasi menurut Oemar Hamalik (2002: 6) yang dapat dikemukakan adalah sebagai berikut: Peranan pendidikan harus dilihat dalam konteks pembangunan secara menyeluruh, yang bertujuan membentuk manusia sesuai dengan cita-cita bangsa. Hasil pendidikan mungkin tidak bisa dilihat dan dirasakan dalam waktu singkat, tetapi baru dilihat dalam jangka waktu yang lama, bahkan mungkin setelah satu generasi.

a. Sekolah adalah suatu lembaga profesional yang bertujuan membentuk anak didik menjadi manusia dewasa yang berkepribadian matang dan tangguh, yang dapat bertanggung jawab terhadap masyarakat dan terhadap dirinya.

b. Sesuai dengan hakikat dan kriteri profesi yang telah dijelaskan di depan, jelas bahwapekerjaan guru harus dilakukan oleh orang yang bertugas selaku guru. 
c. Sebagai konsekuensi logis dari pertimbangan tersebut, setiap guru harus memiliki kompetensi profesional, kompetensi kepribadian, dan kompetensi kemasyarakatan.

Berdasarkan ciri-ciri suatu profesi, setiap profesi tentunya mempunyai kode etik yang diatur sebagai pedoman tingkah laku orang yang bertindak sebagai pelaku profesi tertentu, begitu juga dengan guru.

Guru adalah jabatan profesional yang memerlukan berbagai keahlian khusus. Sebagai suatu profesi, maka harus memenuhi kriteria profesional, (hasil lokakarya pembinaan Kurikulum Pendidikan Guru UPI Bandung) dalam Oemar Hamalik (2002: 37-38) sebagai berikut:

a) Fisik

$\checkmark$ Sehat jasmani dan rohani.

$\checkmark$ Tidak mempunyai cacat tubuh yang bisamenimbulkan ejekan/cemoohan atau rasa kasihan dari anak didik.

b) Mental/kepribadian

$\checkmark$ Berkepribadian/berjiwa Pancasila.

$\checkmark$ Mampu menghayati GBHN.

$\checkmark$ Mencintai bangsa dan sesama manusia dan rasa kasih sayang kepada anak didik.

$\checkmark$ Berbudi pekerti yang luhur.

$\checkmark$ Berjiwa kreatif, dapat memanfaatkan rasa pendidikan yang ada secara maksimal.

$\checkmark$ Mampu menyuburkan sikap demokrasi dan penuh tenggang rasa.

c) Keilmiahan/pengetahuan

$\checkmark$ Memahami ilmu yang dapat melandasi pembentukan pribadi.

$\checkmark$ Memahami ilmu pendidikan dan keguruan dan mampu menerapkannya dalam tugasnya sebagai pendidik.

$\checkmark$ Memahami, menguasai serta mencintai ilmu pengetahuan yang akan diajarkan.

$\checkmark$ Memiliki pengetahuan yang cukup tentang bidang-bidang yang lain.

$\checkmark$ Senang membaca buku-buku ilmiah.

d) Keterampilan

$\checkmark$ Mampu berperan sebagai organisator proses belajar mengajar.

$\checkmark$ Mampu menyusun bahan pelajaran atas dasar pendekatan struktural, interdisipliner, fungsional, behavior, dan teknologi.

$\checkmark$ Mampu menyusun garis besar program pengajaran (GBPP).

$\checkmark$ Mampu memecahkan dan melaksanakan teknik-teknik mengajar yang baik dalam mencapai tujuan pendidikan.

$\checkmark$ Mampu merencanakan dan melaksanakan evaluasi pendidikan.

\section{KAJIAN LITERATUR}

Pendidikan terasa mengalami tantangan yang sangat kompleks, seiring dengan kompleksitas persoalan di abad ke-21 yang muncul ditengah-tengah masyarakat kita. Oleh karena itu pendidikan di negeri ini mestinya punya konsep tersendiri yang benarbenar sesuai dengan falsafah bangsa Indonesia (Hambali,2015). Dalam lingkup pendidikan yang terkecil yaitu sekolah, guru memegang peran yang amat penting dan strategis. Kelancaran proses seluruh kegiatan pendidikan terutama di sekolah, sepenuhnya berada dalam tanggung jawab para guru.

Guru adalah seorang pemimpin yang harus mengatur, mengawasi dan mengelola seluruh kegiatan proses pembelajaran di sekolah yang menjadi lingkup tanggung 
jawabnya (Yohanes Suharso, 2013)Pendidik menjadi perantara antara manusia, dalam hal ini anak didik dengan penciptanya, yakni Allah swt. Sehingga bisa dikatakan tugas pendidik sama seperti tugas para utusan Allah. Rasulullah, sebagai Mu'allimul Awwal fil Islam (pendidik pertama dalam Islam) telah mengajarkan ayat-ayat Allah kepada manusia, menyucikan jiwa dari dosa, menjelaskan yang baik dan buruk, yang halal dan haram dan berbagai tentang ajaran bermasyarakat.

Dengan demikian, secara umum tugas pendidik adalah sama dengan tugas para Rasul (Fuad Asy Syalhub, 2012). Guru atau pendidik juga merupakan sosok yang akan memberi pengaruh kepada murid atau anak didiknya. Karena itu, seorang guru atau pendidik haruslah orang yang dapat digugu dan ditiru sebagai panutan, baik dari segi pribadi, ilmu dan tingkah lakunya.

\section{PEMBAHASAN}

Salah satu upaya dalam pengembangan profesi guru dengan cara peningkatan dan pengembangan keterampilan dapat diperoleh melalui proses pembelajaran. Pengembangan profesional guru dipelajari dan disajikan dalam sastra relevan di banyak berbeda cara. Tapi selalu merupakan inti dari upaya tersebut adalah memahami bahwa pengembangan profesional adalah tentang guru belajar, belajar cara belajar, dan mengubah pengetahuan mereka praktek untuk kepentingan siswa mereka (Avalos, 2011). Pada prinsipnya, dapat dikatakan bahwa tujuan utama dari pendidikan, secara umum, pencapaian persiapan optimal profesional masa depan.

Salah satu aspek yang menarik untuk dikaji dari sosok seorang guru adalah aspek kinerja, karena kinerja guru menurut merupakan input yang paling penting dalam penyelenggaraan pendidikan (Nadeem \& et.al, 2011). Akan tetapi berdasarkan Fakta menunjukkan kinerja guru masih belum optimal. Belum optimalnya kinerja guru, hal tersebut ditunjukkan antara lain guru tidak membuat Rencana Pelaksanaan Pembelajaran (RPP), mengabaikan kelengkapan administrasi guru, memberikan tugas tanpa adanya proses tatap muka, kurangnya bahan ajar yang menarik penggunaan model dan metode yang monoton, dan evaluasi pembelajaran yang belum optimal.

Mengingat pentingnya kinerja guru dalam pendidikan, maka diperlukan upaya untuk meningkatkan kinerja guru. Berdasarkan teori perilaku dari Luthans banyak faktor yang dapat mempengaruhi kinerja guru. Salah satu faktor yang sangat mempengaruhi kinerja guru tersebut diantaranya adalah faktor pengembangan profesi guru, faktor tersebut yang dijadikan kajian dari penelitian ini.

\section{SARAN}

Berdasarkan penelitian yang telah dilakukan,peneliti mengajukan beberapa saran sebagai berikut.

1) Hasil belajar siswa meningkat dengan diterapkannya model guided discovery learning berorientasi pendidikankarakter, oleh karena itu guru perlumenggunakan model guided discoverylearning berorientasi pendidikan karakter sebagai salah satu alternatif untuk meningkatkan hasil belajar kognitif,psikomotrik dan karakter siswa dengan materi pelajaran yang telah disesuaikan.

2) Ketersediaan ruang laboratorium menunjangkegiatan siswa pada fase pengumpulan data perlu diperhatikan, karena tidak adanya laboratorium dapat menggganggu kegiatan siswa untuk memperoleh pengetahuan. 
3) Penggunaan model guided discovery learning berorientasi pendidikan karakter dapat di munculkan lebih banyak dalam perbaikan karakter siswa sehingga dalam kreteria membudaya dapat dicapai.

4) Perlu adanya penelitian lanjutan untuk mengetahui efektivitas penggunaan modelguided discovery learning berorientasipendidikan karakter dengan tujuan selain hasilbelajar kognitif, psikomotrik dan karakter siswapada materi- materi yang berbeda.

\section{DAFTAR PUSTAKA}

Amstrong, \& Kotler. (2003). Dasar- Dasar Pemasaran, Jilid I, Edisi Kesembilan. Jakarta:

PT. Indeks Gramedia.

Ana-Maria Petrescu, M. N. (2015). Innovative Aspects of the PROFILES Professional Development Programme Dedicated to Science Teachers. Procedia Social and Behavioral Sciences 19, 1355 - 1360 .

Avalos, B. (2011). Teacher professional development in Teaching and Teacher Education

over ten years. Teaching and Teacher Education, 27, 10-20.

Dee, T., \& Wyckoff, J. (2013). Incentives, Selection, and Teacher Performance. National Bureau of Ecomomic Research Working Paper Series.

Elliot, K. (2015). Teacher Performance Appraisal: More about Performance or Development? Australian Journal of Teacher Education, 40(9).

Finch, R, C., \& Crunkilton, J. R. (1999). Curriculum Development in Vocational and Technical Education Planing, Content, and Implementation (5th ed.). Bostom: Allyn and Bacom.

Hameed, A., \& Waheed, A. (2011). Employee Development and Its Affect on Employee Performance A Conceptual Framework. International Journal of Business and Social Science, 2(13).

Hani, T. H. (2001). Manajemen Personalia dan Sumber Daya Manusia. Yogyakarta: BPFE.

Jankingthong, K., \& Rurkkhum, S. (2012). Factors Affecting Job Performance: AReview of Literature. Silpakorn University Journal of Social Science, Humanities, and Arts, 12(2), 115-127.

Jennifer Gallo-Fox, K. S. (2016). Coteaching as professional development for cooperating teachers. Teaching and Teacher Education , 191-202.

Kevin C. Bastian, G. T. (2016). Teacher candidate performance assessments: Local scoring and implications for teacher preparation program improvement. Teaching and Teacher Education 59, 1-12

Fakih, Mansour, 2000. Runtuhnya Teori Pembangunan dan Globalisasi. Yogyakarta: Insist Press dan Pustaka Pelajar.

Freire, Paulo, 2000. Pendidikan Kaum Tertindas, alih bahasa Oetomo Dananjaya dkk. Jakarta: LP3ES.

Joesoef, Daoed, 2001. "Pembaharuan Pendidikan dan Pikiran", dalam Sularto ( ed ). Masyarakat Warga dan Pergulatan Demokrasi: Antara Cita dan Fakta. Jakarta: Kompas.

Karim, M. Rusli. 1991, "Pendidikan Islam sebai Upaya Pembebasan Manusia", dalam Muslih Usa (ed.). Pendidikan Islam di Indonesia: Antara Cita dan Fakta. Yogyakarta: Tiara Wacana. 
Kuntowijoyo, 2001. Muslim Tanpa Masjid: Esai-Esai Agama, Budaya, dan Politik dalam Bingkai Strukturalisme Transendental. Bandung: Mizan.

Maarif, Ahmad Syafii, 1987. "Masalah Pembaharuan Pendidikan Islam", dalam Ahmad Busyairi dan Azharudin Sahil ( ed .). Tantangan Pendidikan Islam. Yogyakarta: LPM UII.

Maarif. Ahmad Syafii, 1996. "Pendidikan Islam dan Proses Pemberdayaan Umat". Jurnal Pendidikan Islam, No. 2 Th.I/Oktober 1996.

Othman, Ali Issa, 1981. Manusia Menurut al-Ghazali, alih bahasa Johan Smit dkk. Bandung: Pustaka.

Shane, Harlod G., 1984. Arti Pendidikan bagi Masa Depan. Jakarta: Rajawali Pers.

Soedjatmoko, 1991. "Nasionalisme sebagai Prospek Belajar", Prisma, No. 2 Th. XX, Februari.

Suyanto, 2006. Dinamika Pendidikan Nasional (Dalam Percanturan Dunia Global). Jakarta: PSAP Muhammadiyah 